\title{
Contents, Volume 5 (1994)
}

Albrecht, A.: Freeze-drying techniques for preserving aphids (Homoptera, Aphidodea) ......................... 105

Albrecht, A. \& Kaila, L.: Elachista fuscofrontella Sruoga (Lepidoptera, Elachistidae) from Estonia, new to Europe, with description of the female ..................... 35

Biström, O. \& Wewalka, G.: Hydrovatus asymmetricus $\mathrm{sp}$. n. (Coleoptera, Dytiscidae) - an enigmatic species from Southeast Asia ............................................ 103

Brodo, F.: The subgenus Tipula (Tipula) in Finland and Estonia 49

Fibiger, M.: see Mikkola, K., Fibiger, M. \& Lafontaine, J. D. 125

Gannota, E. \& Tobias, V.: Dacnusa bakurianensis sp. n. (Hymenoptera, Braconidae) from Caucasus ........... 7

Hansen, M. \& Hämäläinen, H.: Hydraena excisa Ganglbauer (Coleoptera, Hydraenidae) new to Finland

53

Heliövaara, K.; see Väisänen, R., Heliövaara, K. \& Somerma, P. 139

Hippa, H.: see Vilkamaa, P. \& Hippa, H. ..................... 41

Hokkanen, T. J.: see Yakovlev, E. \& Hokkanen, T. J. 203

Hämäläinen, H.: see Hansen, M. \& Hämäläinen, H. ... 53

Itämies, J.: Chromatomyia linnaeae (Diptera, Agromyzidae) new to Finland

Itämies, J. \& Karvonen, J.: The female of Rhigognostis sibirica (Lepidoptera, Plutellidae) 197

Itämies, J.: see Laine, A., Itämies, J., Orell, M. \& Kvist, S. 177

Itämies, J.: see Lakovaara, S. \& Itämies, J................. 149

Jalava, J.: see Kaila, L. \& Jalava, J. ............................... 97

Jalava, J.: see Kozlov, M. V. \& Jalava, J. ..................... 65

Jussila, R.: Aperileptus rossemi $\mathrm{sp}$. n., Aniseres lapponicus sp. n., and additions to descriptions of other Oxytorine species (Hymenoptera, Ichneumonidae). ............ 115

Jussila, R.: Ichneumonidae (Hymenoptera) new to Finland. III. 119

Jussila, R.: Addition to the revision of the genus Atractodes (Hymenoptera, Ichneumonidae) of the western Palaearctic Region. II 129

Kaila, L. \& Jalava, J.: Elachista adelpha sp. n., E. coeneni titanella ssp. n., and other Elachistidae (Lepidoptera) from North Caucasus

Kaila, L.: see Albrecht, A. \& Kaila, L. .......................... 35

Karvonen, J.: see Itämies, J. \& Karvonen, J. .............. 197

Kjaerandsen, J.: Prosciara didactyla sp. n. and $P$. megachaeta Hippa \& Vilkamaa, 1991 from Thailand (Diptera, Sciaridae) 147

Kozlov, M. V. \& Jalava, J.: Lepidoptera of the Kola Peninsula, northwestern Russia
Kurina, O.: Thereva nobilitata (Diptera, Therevidae) reared from Boletales and Agaricales (Basidiomycota) .. 186

Kvist, S.: see Laine, A., Itämies, J., Orell, M. \& Kvist, S. 177

Laasonen, E. M. \& Laasonen, L.: Endothenia oblongana and E. marginana (Lepidoptera, Tortricidae) in Finland, with description of a new subspecies ......... 189

Laasonen, L.: see Laasonen, E. M. \& Laasonen, L. ... 189 Lafontaine, J. D.: see Mikkola, K., Fibiger, M. \& Lafontaine, J. D. 125

Laine, A., Itämies, J., Orell, M. \& Kvist, S.: Invertebrate fauna of Norway spruce (Picea abies) saplings and its connection with the nitrogen, sulphur and phenolics of the needles 177

Lakovaara, S. \& Itämies, J.: Drosophila repleta Wollaston (Diptera, Drosophilidae) new to Finland .............. 149

Linnavuori, R. E.: Hemiptera of Iraq. IV. Heteroptera, the aquatic and subaquatic families, Saldidae and Leptopodidae 87

Linnavuori, R. E.: Heteroptera from Socotra .............. 151 Linnavuori, R. E.: On the Miridae fauna of the Middle East (Heteroptera, Miridae) 205

Mikkola, K., Fibiger, M. \& Lafontaine, J. D.: Revision of the Xestia speciosa and $X$. alpicola complexes in Europe (Lepidoptera, Noctuidae) ......................... 125

Niemi, R.: Oribatid species (Acarina, Oribatei) new to the fauna of Finland 213

Nilsson, A. N.: Two new East Palearctic Agabus species of the adpressus- and confinis-groups (Coleoptera, Dytiscidae) 169

Orell, M.: see Laine, A., Itämies, J., Orell, M. \& Kvist, S. 177

Povolny, D.: New taxa and records of Gnorimoschema Busck and Gobipalpa Povolny from Palaearctic Asia (Lepidoptera, Gelechiidae) ..................................... 57

Ruohomäki, K.: Larval parasitism in outbreaking and nonoutbreaking populations of Epirrita autumnata (Lepidoptera, Geometridae) .................................... 27

Rutanen, I.: Gyrophaena kangasi sp. n. (Coleoptera, Staphylinidae) aus Finnland .................................... 39

Rutanen, I.: Xyletinus tremulicola (Coleoptera, Anobiidae) found in Finland .................................................... 201

Schmidt, S.: see Zinovjev, A. G. \& Schmidt, S. ........ 135

Somerma, P.: see Väisänen, R., Heliövaara, K. \& Somerma,

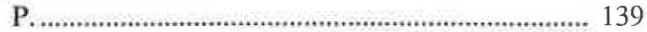

Thunes, K. H.: The coleopteran fauna of Piptoporus betulinus and Fomes fomentarius (Aphyllophorales: Polyporaceae) in western Norway . 157

Tobias, V.: see Gannota, E. \& Tobias, V........................ 7 
Väisänen, R.: New Mycomyinae from South Africa (Diptera, Mycetophilidae) .. 13

Väisänen, R., Heliövaara, K. \& Somerma, P.: Wing variation of Maculinea arion (Linnaeus) in Finland (Lepidoptera, Lycaenidae) 139

Vilkamaa, P. \& Hippa, H.: The genus Lobosciara Steffan (Diptera, Sciaridae) 41

Wewalka, G.: see Biström, O. \& Wewalka, G. ........... 103

Yakovlev, E. \& Hokkanen, T. J.: Cyllodes ater (Coleoptera, Nitidulidae) found again in Finland 203

Zinovjev, A. G. \& Schmidt, S.: Amauronematus compactus Bogacheva and A. harpicola Bogacheva (Hymenoptera, Tenthredinidae) from Polar Urals 135

\section{Short reports}

Albrecht, A.: Aphis klimeschi, A. leontodontis and A. violae (Homoptera, Aphidina) new to Finland .. 3

Albrecht, A.: Aphis epilobaria and A. molluginis (Homoptera, Aphididae) new to Finland .................. 4

Albrecht, A.: Chaitophorus populialbae (Boyer de Fonscolombe) (Homoptera, Drepanosiphidae) new to Finland

Albrecht, A.: Uroleucon pilosellae (Börner) (Homopterea, Aphididae) new to Finland

Clayhills, T.: Interesting Coleoptera found in 1992 ........ 1

Faunistic rarities

Hackman, W.: Two species of Mallophaga (Esthiopteridae), not previously reported from Finland

Koponen, M.: Ablaxia squamifera (Thomson) (Hymenoptera, Chalcidoidea, Pteromalidae) new to Finland ... 5

Mannerkoski, I.: Eucnemis capucina Ahrens (Coleoptera, Eucnemidae) from Helsinki 2 Mannerkoski, I.: Further records of Ptomaphagus sericatus (Chaudoir) (Coleoptera, Cholevidae) in Finland ..... 3
Mannerkoski, I. \& Helve, E.: Clambus nigrellus Reitter (Coleoptera, Clambidae) new to Finland

1

Martikainen, P.: Trichonyx sulcicollis (Reichenbach)

(Coleoptera, Pselaphinae) new to Finland ................ 3

New provincial records .................................................. 6

Rinne, V.: Zygina rosincola (Cerutti, 1939) (Homoptera, Cicadellidae) new to Finland 5

Rutanen, I.: Malthodes misellus Kiesenwetter (Coleoptera, Cantharidae) new to Finland

Rutanen, I., Kangas, J. K. \& Valtonen, P.: New records of Nargus velox (Spence) (Coleoptera, Cholevidae) from Finland and Nargus badius (Sturm) deleted from the fauna of Finland 2

\section{Literature reviews}

Desender, K., Dufrene, M., Loreau, M., Luff, M. L. \& Maelfait, J.-P. (eds): Carabid Beetles: Ecology and Evolution. (Olof Biström) 176 Johnson, C.: Provisional atlas of the Cryptophagidae Atomariinae (Coleoptera) of Britain and Ireland. (Olof Biström) 86

Karg, W. : Acari (Acarina), Milben, Parasitiformes (Anactinochaeta) Cohors Gamasina Leach. Raubmilben. (Pekka T. Lehtinen) ......................... 10

Menken, S. B. J., Visser, J. H. \& Harrewijn, P. (eds): Proceedings of the 8th International Symposium on Insect-Plant Relationships. (Ulf Carlberg) ............ 96

Pittaway, A. R.: The Hawkmoths of the Western Palaearctic. (Jukka Jalava) 56

Spencer, K. A.: Flycatcher. Memoirs of an amateur entomologist. (Hans Silfverberg) 